\title{
Impact of Human Resources Budgeting on Human Resource Management Accountability in Metropolitan, Municipal, and District Assemblies in the Ashanti Region
}

\author{
Laar David Diam \\ Doctor of Philosophy in Business Management, Texila American University, Ghana
}

\begin{abstract}
The Metropolitan, Municipal, and District Assemblies in Ghana have adopted, have been practicing Human Resource Budgeting for effective accounting of human resources. However, little is done to determine its impact on Human Resource Management Accountability. This study, therefore, focused on the impact of Human Resource Budgeting on Human Resource Management Accountability in Metropolitan, Municipal, and District Assemblies (MMDAs) in the Ashanti Region of Ghana. The study purposively sampled Heads of Departments since they have the responsibility of supervising, directing, coordinating the activities of other employees within the MMDAs. The study collected primary data from 387 Heads of Departments in 43 MMDAs in the region. The study employed mean and standard deviation for descriptive analysis. The study employed a structural equation model for the estimation of the impact of Human Resource Budgeting on Human Resource Management Accountability. The sex, educational level, and years of experience of the respondents were controlled for in the model estimation. Human Resource Budgeting in the MMDAs was occasionally done. Human Resource Budgeting had a significant positive impact on Human Resource Management Accountability in the MMDAs. Ministry of Local Government and Rural Development should see Human Resource Budgeting as a strategic tool for enhancing Human Resource Management Accountability in MMDAs. For this reason, Human Resource budgeting practices should be enforced to the latter.
\end{abstract}

Keywords: Human Resource Budgeting, Human Resource Management Accountability, Metropolitan, Municipal and District Assemblies.

\section{Introduction}

Human capital is an important component since it has the capacity to improve or degrade an organization's performance [1]. For this reason, every organization or institution deems it appropriate to it manage human resource with maximum care. In recent times, Human Resource Budgeting has been introduced to provide $\mathrm{s}$ standard practice for measuring the value and cost of people in an organization, cost of recruitment, hiring, training, and development [2]. The human resources budget refers to the funds that human resource allocates to all human resource processes enterprise wide. The Human resource budge includes funds allocated to hiring, salaries, benefits, talent management, training, succession planning, workforce engagement, and employee wellness planning. HR budgets use financial information, performance results, and historical data from every department. Since the HR budget considers HR activities company-wide, it is an incredibly complex yet essential document to determining a company's future Human activities and accountability [3]. Any accounting practice, including Human Resource Budgeting practice, is to help ensure accountability. Human 
Resource Management Accountability of Departmental Heads in Metropolitan, Municipal and District Assemblies (MMDAs) entails establishing and maintaining effective human resource management policy, delegating human resource management responsibilities through formal delegation agreements, monitoring and providing corporate and organizational-level reporting on human resources matters; representing the employer at the corporate-wide level and ensuring that non-delegated human resource management responsibilities are carried out in a manner consistent with applicable legislation, collective agreements [4]. Human Resource Budget is designed to improve Human Resource Management Accountability and performance [5].

Empirically, the link between Human Resource Budgeting and HRM accountability has been established in corporate entities in developed countries. For example, Enyi and Akindehinde [6] has demonstrated Human Resource Budgeting significantly affects management decisions and enhanced accountability. Similarly, Islam, Kamruzzaman, and Redwanuzzaman [7] noted that Human Resource Budgeting practice has helped improve accountability in organizations and the productivity of employees as well. However, the outcomes of these studies cannot be applied to Ghana since Ghana has political, economic, social, and cultural characteristics different from those developed countries where such studies were done. More importantly, all the empirical studies were carried out in private corporate entities but not the public sector, where accountability is a major issue. In Ghana, the public's desire for accountability from public workers at all levels is increasing [8]. The Metropolitan, Municipal, and District Assemblies (MMDAs) in Ghana have all been at the forefront of the debate over accountability, though Human Resource Budget is being implemented. This has raised many questions, including, what is the extent to which Human Resource Budgeting is practiced in MMDAs? and Does Human Resource Budgeting really improve HRM accountability within the MMDAs in Ghana? Addressing the above questions would help the human resources practitioners and the Government of Ghana to be aware of what should be done to promote the effective practice of Human Resource Budgeting in MMDAs to enhance HRM accountability.

\section{Methods}

\section{Description of the Site}

This study was conducted in Ashanti of Ghana. The Ashanti Region is located in south Ghana, and it is the third largest of 16 administrative regions, occupying a total land surface of $24,389 \mathrm{~km}^{2}(9,417$ sq. mi) or 10.2 percent of the total land area of Ghana. In terms of population, however, it is the most populated region with a population of 4,780,380 according to the 2010 census, accounting for $19.4 \%$ of Ghana's total population. Kumasi is the capital town of the Ashanti Region. The region has 1 Metropolitan Assembly, 20 Municipal Assemblies, and 24 District Assemblies as Shown in Table 1.

Table 1. MMDAs in the Ashanti Region of Ghana

\begin{tabular}{|l|l|l|l|}
\hline Region & Metropolis & Municipals & Districts \\
\hline Ashanti Region & Kumasi Metropolis & Ahafo Ano North Municipal & Adansi Asokwa \\
\cline { 3 - 4 } & & Asante Akim Central & Adansi North \\
\hline \multirow{5}{*}{} & Asokore Mampong & Adansi South \\
\hline \multirow{5}{*}{} & Asokwa & Afigya-Kwabre North \\
\hline & Atwima Nwabiagya & Afigya-Kwabere South \\
\hline & Asante Akim South & Ahafo Ano Southwest \\
\hline & Amansie East & Ahafo Ano Southeast \\
\hline
\end{tabular}




\begin{tabular}{|l|l|l|}
\hline & Bekwai & Akrofuom District \\
\hline & Kwadaso & Amansie Central \\
\hline Ejisu & Amansie West \\
\hline Mampong & Amansie South \\
\hline & Obuasi & Asante Akim North \\
\hline & Offinso & Atwima Kwanwoma \\
\hline & Oforikrom & Atwima Mponua \\
\hline Old Tafo & Atwima Nwabiagya North \\
\hline Suame & Bosome Freho \\
\hline Kwabere East & Bosomtwe \\
\hline & EjuraSekyedumase & Obuasi East \\
\hline Juaben & Offinso North \\
\hline & Sekyere Afram Plains \\
\hline & Sekyere Central \\
\hline & Sekyere East \\
\hline & Sekyere South \\
\hline
\end{tabular}

Source: Ministry Local Government and Rural Development (2021)

\section{Description of Experiment}

The study, through the purposive sampling technique, sampled Departmental Heads in MMDAs in the Ashanti Region. However, two District Assemblies could not give their consent on time; hence they were ignored in the study.
Therefore, the Metropolitan Assemblies was 1, and Municipal Assemblies were 20, and District Assemblies were 22, making a total of 43 MMDAs in the study. The total number of Heads of Departments from the Metropolitan Assembly, Municipal Assemblies, and District Assemblies are shown in Table 2.

Table 2. Number of Respondents

\begin{tabular}{|l|l|}
\hline Departments & Number of Heads \\
\hline Finance & 43 \\
\hline Administration & 43 \\
\hline Community Development and Works & 43 \\
\hline Social Welfare & 43 \\
\hline Physical Planning & 43 \\
\hline Trade and Industry & 43 \\
\hline Health & 43 \\
\hline Agriculture & 43 \\
\hline Education & 43 \\
\hline Total & 387 \\
\hline
\end{tabular}

Source: Author's Construct (2021)

Thus, the total number of respondents used in this study was 387 . The study used questionnaire to collect the data from respondents. The questionnaire had three sections. Part I: Sociodemographic characteristics of respondents comprised of gender, educational level, and years of working experience. Part II focused on human resource budgeting practice which had 8 items with a four-point Likert scale from rarely (1) to very often (4). Part III focused on Human 
Resource Management accountability of Departmental Head, and it had 5 items with four point-Likert scale ranging from strongly disagree (1) to strongly agree (4) with no neutral position. The questionnaire was reliability with an overall Cronbach's Alpha of 0.891 (i.e., $\alpha=0.891$ ) and valid with Factor Loading Score for each item more than 0.4 and the KaiserMeyer-Olkin (KMO) for each construct was more than 0.8 .

\section{Statistical Method}

The data were analysed using Statistical Package for Social Sciences (SPSS), version 21.0, and STATA version 15.0. The study edited the data, coded the data, and entered them into the software for analysis. The study used SPSS, version 21.0, for all the descriptive analysis, whiles STATA was used to estimate of the model. The used mean and standard deviation for the descriptive analysis. The mean scores ranged 1.00-1.49, 1.50-2.49, 2.50-3.49, 3.504.00which rarely represented, occasionally, often, and very often respectively for Human
Resource Budgeting statements and strongly disagree, disagree, agree, and strongly agree respectively for Humans Resource Management accountability. To determine the effect of human resource budgeting on human resource accountability of Departmental Heads, this study used Structural Equation Model as suggested by Kline [9]. The models are specified below.

$H R M A o D H=\propto_{0} H R M B+\propto_{1} S E X+$ $\propto_{2} E D U L+\propto_{3} Y E X+\varepsilon \ldots \ldots \ldots \ldots . .$. Model 1

Where HRMAoDH is the human resource management accountability of the Departmental Head and HRMB is the Human Resource Budgeting. SEX, EDUL, and YEX denote sex, educational level, and years of working experience in the assemblies, respectively. The acceptable level of significance was $5 \%$.

\section{Results}

\section{Personal Information of Respondents}

The study gathered relevant personal information of the respondents, and they are presented in Table 3.

Table 3. Socio-demographic Characteristics of Respondents ( $\mathrm{N}=387)$

\begin{tabular}{|l|l|l|l|}
\hline Variables & Categories & Frequency & Percentage \\
\hline \multirow{3}{*}{ Sex } & Male & 263 & 67.96 \\
\cline { 2 - 4 } & Female & 124 & 32.04 \\
\hline \multirow{5}{*}{ Yevel of education } & Diploma & 43 & 11.11 \\
\cline { 2 - 4 } & Degree & 187 & 48.32 \\
\cline { 2 - 4 } & Masters' Degree & 157 & 40.57 \\
\hline \multirow{3}{*}{ Years of experience } & $1-5$ years & 78 & 20.16 \\
\cline { 2 - 4 } & 6-10 years & 179 & 46.25 \\
\cline { 2 - 4 } & Above 10 years & 130 & 33.59 \\
\hline
\end{tabular}

Source: Field Data (2021)

The results in Table 3 indicate that males dominated $(67.96 \%)$ as Heads of Departments in MMDAs in the Ashanti Region of Ghana. It is further indicated in Table 3 that almost all the respondents have first degree or master's degree. Given their level of academic qualification, the management members of the MMDAs are expected to have much knowledge in human resource management issues. Most of the respondents $(79.84 \%)$ have served in their respective MMDAs for more than 5 years, and this implies that almost all the respondents are familiar with the human resource accounting practice of the MMDAs.

\section{Human Resource Budgeting Practices Used by MMDA's}

The extent of Human Resource Accounting Practices of the MMDAs are shown in Table 4. 
Table 4. Human Accounting Practices

\begin{tabular}{|l|l|l|l|l|}
\hline Practices & $\begin{array}{l}\text { Weighted } \\
\text { Mean }\end{array}$ & $\begin{array}{l}\text { Standard } \\
\text { deviation }\end{array}$ & $\begin{array}{l}\text { Frequency of } \\
\text { practice }\end{array}$ & Ranking \\
\hline $\begin{array}{l}\text { The assembly practices capitalising and } \\
\text { amortizing over the expected useful life } \\
\text { of human resource for the acquisition } \\
\text { cost of human resource }\end{array}$ & 2.338 & 0.94218 & Occasionally & $5^{\text {th }}$ \\
\hline $\begin{array}{l}\text { The assembly practices capitalising and } \\
\text { amortizing over the expected useful life } \\
\text { of human resource for training and } \\
\text { development cost of human resource }\end{array}$ & 2.4832 & 0.95581 & Occasionally & $3^{\text {rd }}$ \\
\hline $\begin{array}{l}\text { The assembly practices capitalising and } \\
\text { amortizing over the expected useful life } \\
\text { of human resource for the welfare cost } \\
\text { of human resource }\end{array}$ & 2.3333 & 1.09165 & Occasionally & $6^{\text {th }}$ \\
\hline $\begin{array}{l}\text { The assembly practices capitalising and } \\
\text { amortizing over the expected useful life } \\
\text { of human resource for the other } \\
\text { expected costs for human resource. }\end{array}$ & 2.9276 & 1.18056 & Often & $1^{\text {st }}$ \\
\hline $\begin{array}{l}\text { The assembly practices capitalising and } \\
\text { amortizing over the expected useful life } \\
\text { of human resource acquisition cost to } \\
\text { replace human resource presently } \\
\text { employed }\end{array}$ & 2.3127 & 0.83195 & Occasionally & $7^{\text {th }}$ \\
\hline $\begin{array}{l}\text { The assembly practices capitalising and } \\
\text { amortizing over the expected useful life } \\
\text { of human resource learning cost to } \\
\text { replace human resource presently } \\
\text { employed }\end{array}$ & 2.2351 & 1.04510 & Occasionally & $8^{\text {th }}$ \\
\hline $\begin{array}{l}\text { The assembly practices capitalising and } \\
\text { amortizing over the expected useful life } \\
\text { of human resource separation cost to } \\
\text { replace human resource presently } \\
\text { employed }\end{array}$ & 2.4625 & 1.01824 & Occasionally & $4^{\text {th }}$ \\
\hline $\begin{array}{l}\text { The assembly practices capitalising and } \\
\text { amortising bidding cost of scarce } \\
\text { employees within bid the organisation }\end{array}$ & 2.8346 & 1.13974 & Often & \\
\hline Total score & 2.4909 & 1.14251 & Occasionally & \\
\hline
\end{tabular}

Source: Filed Data (2021)

Table 4 above shows that Human Resource budgeting practices is occasionally practiced in the MMDAs in the Ashanti region of Ghana. The MMDAs occasionally capitalise and amortize the expected useful life of human resource for the acquisition cost of human resources; for training and development cost of human resource, for the welfare cost of human resource, and to replace human resource presently employed. However, the MMDAs often 
capitalise and amortize the expected useful life of human resource for the other expected costs for human resource and the bidding cost of scarce employees.

\section{Effect of Human Resource Budgeting on Human Resource Management Accountability}

The study employed Structural Equation Model to estimate the effect of Human Resource Budgeting on the human resource accountability of Departmental Heads. The study, through Principal Component Analysis, obtained one construct for Human Resource Budgeting from 8 items and another construct for human resource management accountability from 5 items. The study used the personal information of the respondents in Table 3 (sex, educational level, and years of working experience) as control variables. The results of the Structural Equation Model are shown in Figure 1 and Table 5.

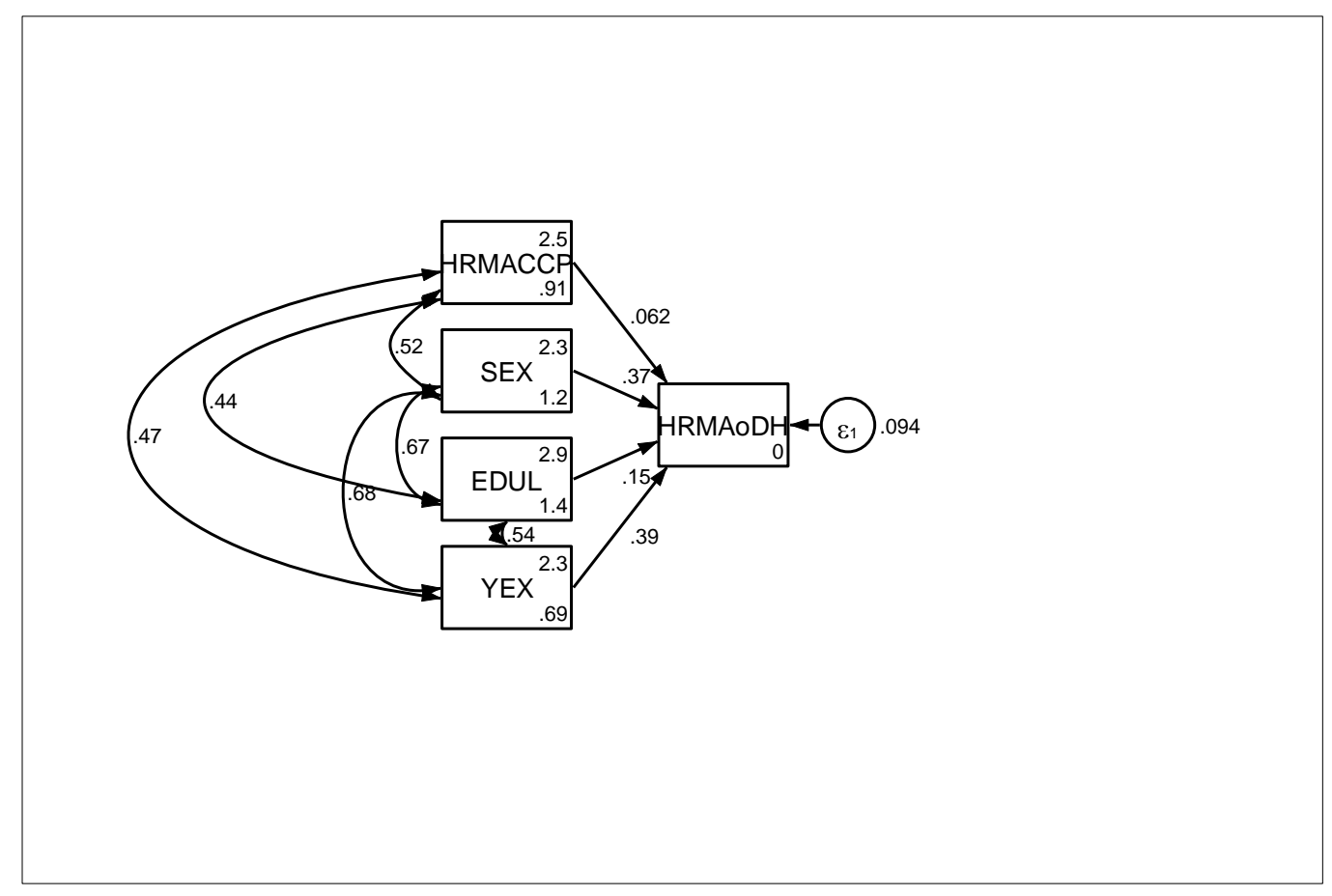

Figure 1. Impact of Human Resource Budgeting on HRM Accountability

Table 5. Impact of Human Resource Budgeting on Human Resource Management Accountability

\begin{tabular}{|l|l|l|l|l|l|}
\hline Variables & Coeff. & OIM & $\mathbf{z}$ & $\mathbf{p}>/ \mathbf{z} /$ & {$[\mathbf{9 5 \%}$ Conf. Interval } \\
\cline { 3 - 6 } & & Std. Err & & & \\
\hline $\begin{array}{l}\text { Human Resource } \\
\text { Accounting }\end{array}$ & 0.0624878 & 0.0192019 & 3.25 & 0.001 & 0.2485280 .1001228 \\
\hline Sex & 0.3658908 & 0.02222 & 16.47 & 0.000 & 0.32234050 .4094411 \\
\hline Educational Level & 0.1505726 & 0.0154103 & 9.77 & 0.000 & 0.1203690 .1807762 \\
\hline $\begin{array}{l}\text { Years of Working } \\
\text { Experience }\end{array}$ & 0.3935086 & 0.0305883 & 12.86 & 0.000 & 0.33355670 .4534605 \\
\hline Constant & 0.13252 & 0.01247 & 10.62 & 0.000 & 0.1173010 .254312 \\
\hline Chi ${ }^{2}$ bs (4) $=889.540 ; \mathrm{p}>\mathrm{Chi}^{2}=0.000$ & & & & \\
\hline
\end{tabular}

Source: Field Data (2021)

The results in Table 5 and Figure 1 show that Human Resource Accounting has a significant positive impact on HRM accountability of Departmental Heads (Coeff. $=0.0624878$; Std. 
Err $=0.0192019 ; p$-value $=0.001)$. As the practice of Human Resource Accounting increases by one unit, HRM accountability significantly increases by 0.0624878 . Sex, educational level, and years of working experiencing of Heads of Departments in MMDAs have a significant positive impact on Human Resource Management accountability. The estimated model is statistically fit for predicting the impact of Human Resource Accounting on HRM accountability in MMDAs in the Ashanti Region of Ghana $\left(\mathrm{Chi}^{2}\right.$ bs (4) $=889.540 ; \mathrm{p}>\mathrm{Chi}^{2}=$ $0.000)$.

\section{Discussions}

The results show that Human Resource Budgeting is occasionally practiced in the MMDAs. This is consistent with some of the previous studies that found that awareness and practice of human resource budgeting is very low, especially in developing countries $[10,11$, 12].

However, the effect practice of Human Resource Accounting significantly improves HRM accountability of Departmental Heads in MMDAs. Similar findings were observed by some previous studies in developed countries in private entities. This finding is consistent with some previous studies. For example, Islam Kamruzzaman and Redwanuzzaman [7] revealed that Human Resource Accounting or Budgeting helps the management in taking various decisions for achieving their organizational goals by accurate estimation of the human resources. The study further revealed that Human Resource budgeting system helps in the personnel selection process, recruitment, estimate cost and budget for the acquisition and development of human resources and also helps in the utilization of human resource effectively by providing better reward administration and it is important in the evaluation process by developing reliable methods of measuring the value of employees to an organization. All these indicate that Human Resource Budgeting enhances accountability of Human Resource
Management within an organization or institution [7]. Dhanabhakyamand Mufliha [13] noted that when human resources activities are quantified and reported, it would help to insist on accountability of Human Resource Management. Other study [14-17] have also confirmed that human resource budgeting improves accountability, leading to higher organizational performance as measure by profitability. However, Shukla and Naghshbandi [18] note that human resource budgeting has no effect on accountability both in the financial and human resource sense. This has been confirmed by other studies that there is limited evidence on the relationship between human resource budgeting and human resource accountability $[19,20]$.

\section{Conclusion}

The study assessed the practice of Human Resource Accounting and its effect of HRM accountability in MMDAs in the Ashanti Region of Ghana. The based on the findings from the study, it is concluded that Human Resource Accounting is occasionally practiced in MMDAs. Effective practice of Human Resource Accounting significantly improves HRM accountability. The study recommends the effective and efficient practice of Human Resource Accounting as a strategy to promote accountability in the area of HRM in MMDAs.

Though the study is very relevant and first in its king, it is limited to the MMDAs in the Ashanti Region. Future studies should replicate this study in other regions and in other public institutions and organizations for a comprehensive understanding of Human Resource Accounting practice and its effect in HRM accountability in Ghana.

\section{Acknowledgement}

My sincerest gratitude to Dr. Freda Ocansey, Mr. Prince Amoako who offered very valuable contributions and were very supportive in the compilation of this article. I take this opportunity to thank Anitha, my research mentor, my office 
secretary, who did the typesetting of this manuscript. Ms. Mary Yigal, how can I forget you? Your kindness and love were just indescribable.

I will remain grateful. Mrs. Diam Lilian Laar, my wife, you were, and you remain, my solid

\section{References}

[1] Kodwani, D., Deo, A., and Tiwari, R., 2007, Human resource accounting-a new dimension. In Canadian Accounting Association (CAAA) 2006 Annual Conference.

[2] Fremont-Smith, M., 2004, Pillaging of Charitable Assets: Embezzlement and Fraud. Exempt Organization Tax Review, 46(33), pp. 333-346.

[3] Akintoye, I. R., Awoniyi, O., Jayeoba, O., and Moses Ifayemi, O., 2016, Improvement of human resource accounting disclosure practice in financial statements through IFRS: evidence from Nigerian Banks. International Journal of Business and Commerce, 5(7), 1-17.

[4] Ministry of Local Government and Rural Development.

[5] Surarchith N. K. Vaddadi K. M. and Cura F., 2017, Impact of Human Resource Accounting (HRA) on the Performance of a Firm, International Journal of Management and Applied Science, Volume-3, Issue-10.

[6] Enyi E. P. and Akindehinde A.O., 2014, Human Resource Accounting and Decision Making in PostIndustrial Economy, International Journal of Accounting and Taxation, Vol. 2, No. 1, pp. 19-35.

[7] Islam A., Kamruzzaman, R. and Redwanuzzaman, M., 2013, Human Resource Accounting: Recognition and Disclosure of Accounting Methods \& Techniques, Global Journal of Management and Business Research Accounting and Auditing, Volume 13 Issue 3.

[8] Asiedu, K. F., and Deffor, E. W., 2017, Fighting corruption by means of effective internal audit function: Evidence from the Ghanaian public sector. International Journal of Auditing, 21(1), 82-99.

[9] Kline, R. B., 2011, Principles and practice of structural equation modeling (3rd ed.). Guilford Press. aids and support. I could not have made it without you.

\section{Conflict of Interest}

The author declares that there is no conflict of interest with regard to this paper.

[10] Oluwatoyin, A.S., 2014, Human Resource Accounting and Disclosure in Financial Statements: Literature Review. Research Journal of Finance and Accounting 5 (22) 72. Retrieved from http://www.iiste.org/journals.

[11]Cherian, J. and Farouq, S., 2013, A Review of Human Resource Accounting and Organizational Performance. International Journal of Economics and Finance, 5 (8) 74-79. http://dx.dpo.org/10.5539/ijef.v5n8p74.

[12]Bullen, M.L., 2007, Human Resource Accounting: A Useful Tool for Measurement and Management in Organizations. Leadership and Organizational Management Journal, 2 (8), 85-103. [13] Dhanabhakyam M. and Mufliha S., 2016, Impact of human resource accounting system on the decisions making areas of human resource management practices, International Journal of Applied Research 2016; 2(5): 505-508.

[14] Ezejiofor R. A., John-Akamelu R. C., and Iyidiobi F. C., 2017, Appraisal of human resource accounting on profitability of the corporate organization. Economics. 6(1), 1-10.

[15]Edom, G.O., Inah, E.U. and Eyisi, A.S., 2015, The impact of human resource accounting on the profitability of a firm: empirical evidence from Access Bank of Nigeria. European Journal of Accounting, Auditing, and Finance Research, 3(7).

[16] Enofe, A.O., Mgbame, C. Sunday O.S. and Ovie, O., 2013, Human resources accounting disclosures in Nigeria quoted firms. Research Journal of Finance and Accounting, 4(13), 1-15.

[17]Rao, A. L., 2014, Human Resource Accounting: A Framework for Better Financial Accounting and Reporting. IOSR Journal of Business and Management, 16, 86-90.

[18] Shukla, A. and Naghshbandi, M., 2015, Comparative Analysis of Human Resource 
Accounting (HRA) Practices in Indian Companies, International Journal of Research and Development - A Management Review (IJRDMR), 4(4), 1-7.

[19] Marler, J. H. and Boudreau, J. W., 2017, An Evidence-Based Review of HR Analytics. The International Journal of Human Resource Management, 28, 3-26.
[20] Kariyawasam, H., 2016, Relationship between Accounting Information and Human Resource Management Related Strategic Decision Making in Sri Lankan Manufacturing Companies. IOSR Journal of Business and Management, 18, 8-12. 